\title{
CALCIUM HYDROXYAPATITE SUPPORTED COBALT CATALYSTS FOR ETHANOL STEAM REFORMING: EFFECT OF THE INCORPORATION METHOD OF ACTIVE PHASE
}

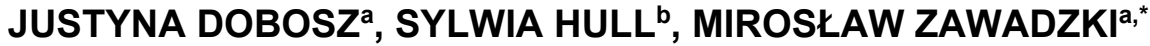

\begin{abstract}
Cobalt catalysts supported on calcium hydroxyapatite $\left(\mathrm{Ca}_{10}\left(\mathrm{PO}_{4}\right)_{6}(\mathrm{OH})_{2}, \mathrm{HAp}\right)$ and modified with cerium ions were prepared in two different ways: direct microwave-assisted hydrothermal synthesis or incipient wetness impregnation method and characterized by XRD, TEM, SEM/EDS, FT-IR and Raman spectroscopy, $\mathrm{N}_{2}$ adsorption-desorption, TPD- $\mathrm{NH}_{3}$, TPR $-\mathrm{H}_{2}$ and XPS. The results indicate that $\mathrm{Ca}^{2+}$ ions in the hydroxyapatite lattice are substituted by $\mathrm{Co}^{2+}$ and $\mathrm{Ce}^{3+}$ under hydrothermal conditions while cobalt and cerium species are formed on the HAp surface during support impregnation. Catalytic activity of samples was tested for hydrogen production via ethanol steam reforming (SRE), and it was found that the highest hydrogen yield (over $3,5 \mathrm{~mol} \mathrm{H} / 2 / \mathrm{mol} \mathrm{C}_{2} \mathrm{H}_{5} \mathrm{OH}$ ) and the best distribution of products were obtained for the catalyst prepared by the incipient wetness impregnation method. For this catalyst, Co species formed on the HAp surface was easier reducible than $\mathrm{Co}^{2+}$ ions located in the HAp crystal lattice, and surface was characterized by lower acidity.
\end{abstract}

Keywords: Cobalt Catalysts, Hydroxyapatite, Hydrothermal Synthesis, Ethanol Steam Reforming.

\section{INTRODUCTION}

Hydrogen is defined as the energy carrier of the future due to its the highest energy content per unit of weight $(120,7 \mathrm{~kJ} / \mathrm{g})$ [1]. Additionally, it burns cleanly, without pollutants emission such as $\mathrm{SO}_{\mathrm{x}}, \mathrm{NO}_{\mathrm{x}}, \mathrm{CO}$ or volatile

\footnotetext{
a Institute of Low Temperature and Structure Research, Department of Nanomaterials Chemistry and Catalysis, Polish Academy of Sciences, PO Box 1410, 50-950 Wrocław, Poland.

b Wrocław University of Technology, Division of Chemistry and Technology Fuels, Gdańska 7/9, 50 - 344 Wrocław, Poland.

*Corresponding author: m.zawadzki@int.pan.wroc.pl
} 
organic compounds (VOC). Nowadays, approximately $95 \%$ of hydrogen is produced through the steam reforming of natural gas [2]. However, the depletion of fossil fuel resources and growing environmental problem tend to seek a new method of hydrogen production. The steam reforming of ethanol (SRE) is considered to be a promising approach for obtaining $\mathrm{H}_{2}$ from an environmentally friendly and renewable energy source. In addition to typical features of bio-based fuels (for example $\mathrm{CO}_{2}$ neutrality), ethanol can be produced by fermentation of biomass such as sugar cane, corn, and their waste material. Moreover, it is characterized by relatively high hydrogen content, easy storage, safe handling, wide availability and significant lower toxicity than methanol [3]. Theoretically, this method of hydrogen production assumes the formation of only two products: hydrogen and carbon dioxide, according to the reaction (1):

$\mathrm{C}_{2} \mathrm{H}_{5} \mathrm{OH}+3 \mathrm{H}_{2} \mathrm{O} \rightarrow 2 \mathrm{CO}_{2}+6 \mathrm{H}_{2} \quad \Delta \mathrm{H}_{298}=174 \mathrm{~kJ} \mathrm{~mol}^{-1}$

However, in practice selectivity toward $\mathrm{H}_{2}$ can be governed by a number of other reactions with the formation of several intermediates and by-products [4-5]. The main pathways include the following reactions:

$$
\begin{array}{ll}
\mathrm{C}_{2} \mathrm{H}_{5} \mathrm{OH} \rightarrow \mathrm{CO}+\mathrm{CH}_{4}+\mathrm{H}_{2} & \text { (ethanol decomposition) } \\
\mathrm{C}_{2} \mathrm{H}_{5} \mathrm{OH}+\mathrm{H}_{2} \mathrm{O} \rightarrow 2 \mathrm{CO}+4 \mathrm{H}_{2} & \text { (incomplete reforming) } \\
\mathrm{CO}+\mathrm{H}_{2} \mathrm{O} \leftrightarrow \mathrm{CO}_{2}+\mathrm{H}_{2} & \text { (water - gas shift, WGS) } \\
\mathrm{C}_{2} \mathrm{H}_{5} \mathrm{OH} \rightarrow \mathrm{CH}_{3} \mathrm{CHO}+\mathrm{H}_{2} & \text { (dehydrogenation) } \\
\mathrm{C}_{2} \mathrm{H}_{5} \mathrm{OH} \leftrightarrow \mathrm{C}_{2} \mathrm{H}_{4}+\mathrm{H}_{2} \mathrm{O} & \text { (dehydration) } \\
\mathrm{CO}+3 \mathrm{H}_{2} \leftrightarrow \mathrm{CH}_{4}+\mathrm{H}_{2} \mathrm{O} & \text { (methanation) } \\
2 \mathrm{CO} \leftrightarrow \mathrm{C}+\mathrm{CO}_{2} & \text { (Boudouard reaction) } \\
2 \mathrm{C}_{2} \mathrm{H}_{5} \mathrm{OH} \rightarrow \mathrm{CH}_{3} \mathrm{COCH}_{3}+\mathrm{CO}+3 \mathrm{H}_{2} & \text { (ethanol decomposition) }
\end{array}
$$

The occurrence of particular reaction during SRE process depends on the nature of catalysts used and the reaction conditions [5].

Catalysts utilize in SRE could be divided into three groups: noble metal catalysts, base metal catalysts and oxide catalysts [6]. Noble metal catalysts (Rh, Ru, Pd, Pt or Ir based) exhibit high hydrogen yield and ethanol conversion [7]. In comparison to the base metal catalysts, the noble metal catalysts show a higher catalytic activity [8] for steam reforming of ethanol but are very expensive. Non-noble metal catalysts based on Co, Cu or $\mathrm{Ni}$ also exhibit good catalytic performance for hydrogen production [9-12] and are less expensive alternative. Among them, especially cobalt-based materials are reported as catalysts ensuring a high conversion of ethanol and selectivity to hydrogen as well as good products distribution due to their capacity for 
C-C bond cleavage [9-10]. However, cobalt catalysts can be easily deactivated by carbon deposition or sintering. To prevent against deactivation process, cerium ions are used. Ceria, in fact, limits ethanol dehydration to ethylene (a well-known coke precursor), contributes to water gas shift reaction, due to its excellent oxygen mobility, promotes the gasification/oxidation of deposited carbon as soon it forms [13]. Nevertheless, to improve the performances of these catalysts, a suitable support and its convenient preparation method should be used.

Several compounds have been studied as supports or host of Co based catalysts [14]. Co supported on $\mathrm{Al}_{2} \mathrm{O}_{3}, \mathrm{ZrO}_{2}$ and $\mathrm{TiO}_{2}$ were studied by Song et al. [15] and they found that $\mathrm{Co} / \mathrm{ZrO}_{2}$ showed the best dispersion and the best catalytic activity in SRE. Over the $10 \mathrm{wt} \% \mathrm{Co} / \mathrm{ZrO}_{2}$ catalyst, using water to ethanol molar ratio of $10: 1$ and $\mathrm{GHSV}=5000 \mathrm{~h}^{-1}$, a total conversion and yield of $5.5 \mathrm{~mol}$ $\mathrm{H}_{2} / \mathrm{mol} \mathrm{EtOH}$ were obtained at $550^{\circ} \mathrm{C}$. In the study conducted by Batista et al. [16], $\mathrm{Co} / \mathrm{Al}_{2} \mathrm{O}_{3}$ (8.6 wt\%), $\mathrm{Co} / \mathrm{SiO}_{2}(7.8 \mathrm{wt} \%)$, and $\mathrm{Co} / \mathrm{MgO}$ (18 wt\%) were examined for hydrogen production via SRE process. The authors reported that all catalysts showed high catalytic activity (>90\% ethanol conversion) and selectivity to hydrogen (about $70 \%$ ). However, the catalysts deactivation by coke formation after $9 \mathrm{~h}$ time-on-stream was detected. Llorca et al. [17] prepared Co catalysts with several supports $\left(\mathrm{ZnO}, \mathrm{MgO}, \mathrm{Al}_{2} \mathrm{O}_{3}, \mathrm{SiO}_{2}, \mathrm{TiO}_{2}, \mathrm{~V}_{2} \mathrm{O}_{5}, \mathrm{La}_{2} \mathrm{O}_{3}, \mathrm{CeO}_{2}\right.$ and $\mathrm{Sm}_{2} \mathrm{O}_{3}$ ) and found that $\mathrm{Co} / \mathrm{ZnO}$ catalyst showed the best catalytic performances. This catalyst showed total conversion and over $40 \%$ of $\mathrm{H}_{2}$ selectivity at $450{ }^{\circ} \mathrm{C}$. Hydrotalcites have been also studied as supports of Co catalysts. Contreras et al. [18] demonstrate that addition of tungsten to the hydrotalcite produced great catalytic stability and high $\mathrm{H}_{2}$ selectivity The addition of $1 \mathrm{wt} \% \mathrm{~W}$ to the hydrotalcite caused an $\mathrm{H}_{2}$ selectivity of $70 \%$ at $450{ }^{\circ} \mathrm{C}$ after $6 \mathrm{~h}$. Lin et al. [19] observed a synergistic effect of $\mathrm{ZrO}_{2}$ and $\mathrm{CeO}_{2}$ to promote high ethanol conversion when $\mathrm{CeZrO}_{4}$ was used as a support of Co catalyst. The $\mathrm{Co} / \mathrm{CeZrO}$ catalysts showed higher catalytic performance (to produce $\mathrm{H}_{2}$ ) than $\mathrm{Co} / \mathrm{ZrO}_{2}$ as a result of methanation suppression. Banach et al. [20] prepared another trimetalic $\mathrm{Co} / \mathrm{ZnO}-\mathrm{Al}_{2} \mathrm{O}_{3}$ catalyst and found that alumina stabilized zinc oxide support. Among studied catalysts, $24 \mathrm{wt} \% \mathrm{Co} / \mathrm{ZnO}+5 \mathrm{wt} \% \mathrm{Al}_{2} \mathrm{O}_{3}$ was the best for SRE process. Wang et al. [21] reported that $\mathrm{CO}_{3} \mathrm{O}_{4}-\mathrm{CeO}_{2}$ catalysts were very active and selective for SRE. It was also shown by Ma et al. [22] that the presence of $\mathrm{Co}_{3} \mathrm{O}_{4}$ phase increased the reactivity toward $\mathrm{H}_{2}$ production in $\mathrm{Zn}$ doped $\mathrm{LaCoO}_{3}$ catalysts. Most of these Co-based catalysts were prepared by coprecipitation and incipient wetness impregnation method, and only some of them by complexing-citrate or hydrothermal method. Apart from the nature of the support used, the synthesis conditions are also important parameters determining the activity and stability of Co-based catalyst. Kaddouri and Mazzocchia [23] reported that cobalt supported alumina and silica catalysts 
prepared by different methods (impregnation, sol-gel and combination of both), exhibited various surface area, surface composition and metal dispersion. These distinct physicochemical properties resulted in an apparent difference in $\mathrm{H}_{2}$ selectivity and products distribution. Therefore, the selection of proper support for cobalt catalyst and the methods of catalysts preparation significantly affect the activity of catalysts during SRE process.

Calcium hydroxyapatite $\left(\mathrm{Ca}_{10}(\mathrm{PO} 4)_{6}(\mathrm{OH})_{2}, \mathrm{HAp}\right)$ is an inorganic compound used as biomaterial, chromatographic absorbent and catalyst [24-26]. In the field of catalysis, HAp is attractive material due to its thermal stability over a wide range of temperature, acid - base properties, high porosity, mesoporous structure and adsorption capacity [27-28]. The hydroxyapatite was found as useful catalysts support for the decomposition of methane [29], removal of oxygenated volatile organic compounds [30] and propane oxidation [31]. HAp was also investigated in reactions for hydrogen production such as glycerol steam reforming [32] and hydrolysis of sodium borohydride [33].

In the literature, several methods of nanosize hydroxyapatite synthesis have been described, for example: precipitation [30], sol - gel [34], hydrothermal reactions [35], microemulsion [36] and soft solution freezing method [37]. Among them, the hydrothermal method is one of the most interesting techniques used for the synthesis of nonoscale materials due to its simplicity, low energy consumption and good environmental aspects. It is reported as a route for obtaining well-dispersed, homogenous products with controlled shapes, sizes and structures [38]. Moreover, a combination of hydrothermal synthesis and microwave radiation reduces significantly reaction time essential to receive the proper crystal structure.

In our previous paper [39] we studied the effect of the HAp preparation method on the properties of cobalt/cerium catalysts used for SRE process. The aim of the present work was to examine the properties of these systems, including their catalytic behavior in SRE, where active metal phase was incorporated in different ways: by direct microwave-hydrothermal synthesis or incipient wetness impregnation method.

\section{RESULTS AND DISCUSSION}

\section{XRD characterization}

The phase composition and crystal structure of the studied catalysts were evaluated by XRD method and diffractogram patterns are presented in Fig. 1. XRD measurements reveal that all synthesized materials have a well-formed hexagonal hydroxyapatite structure crystallized in $\mathrm{P}_{3} / \mathrm{m}$ space group (PDF No 09-0432). However, the substitution as well as the impregnation 
with cobalt and cerium ions causes the appearance of additional peaks in the diffraction patterns. After the substitution, small peaks corresponding to cerium phosphate (PDF No. 04-0632) are observed. It indicates that only a part of $\mathrm{Ce}^{3+}$ ions was incorporated into the HAp crystal structure whereas the other cerium ions form a $\mathrm{CePO}_{4}$ phase. Formation of $\mathrm{CePO}_{4}$ on the surface of calcium hydroxyapatite substituted with cerium ions was suggested by Yasukawa et al. [40]. They reported that only $1 \mathrm{at} \%$ of cerium ions can be incorporated into the HAp structure. Increase of cerium content results in the formation of $\mathrm{CePO}_{4}$ on the hydroxyapatite surface. In case of the impregnation sample, the cerium ions formed a cerium dioxide phase (PDF No. 02-1306) on the support surface. The XRD pattern of the catalyst prepared by impregnation method also shows the peak at $37^{\circ}$ ascribed to $\mathrm{Co}_{3} \mathrm{O}_{4}$ phase (PDF No. 01-1152).

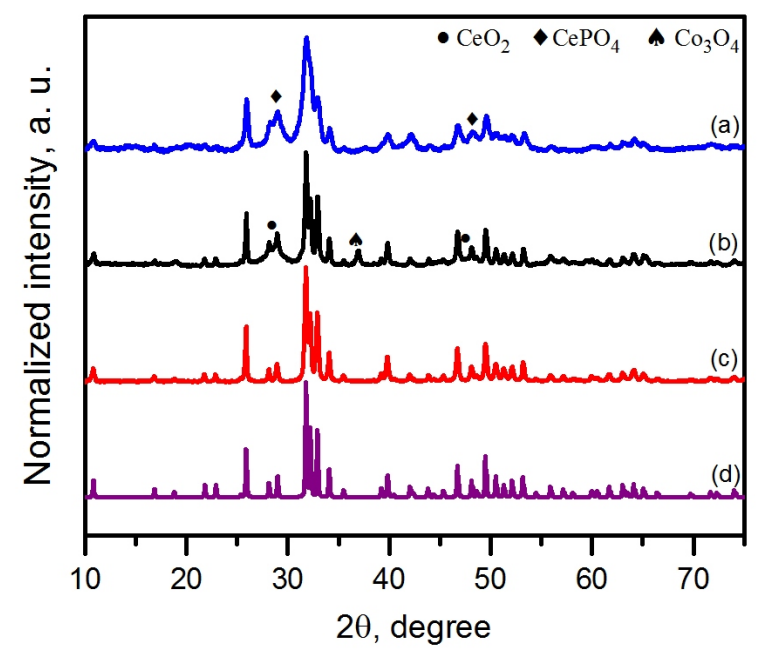

Fig. 1. XRD patterns of (a) 5Co10Ce:HAp, (b) 5Co10Ce/HAp, (c) HAp and (d) standard diffraction pattern of HAp (PDF No. 09-0432).

The unit cell parameters were calculated on the basis of peaks at around $26^{\circ}, 34^{\circ}$ and $53^{\circ}$, which do not overlap with any peaks of additional phases. Results (Table 1) show that lattice constants of 5Co10Ce:HAp decrease after introduction of cobalt and cerium ions due to the substitution of $\mathrm{Ca}^{2+}$ ions (ionic radius: $0,100 \mathrm{~nm}$ ) by smaller $\mathrm{Co}^{2+}$ (ionic radius: 0,0078 $\mathrm{nm})$. The ionic radius of $\mathrm{Ce}^{3+}(0,101 \mathrm{~nm})$ is comparable with ionic radius of $\mathrm{Ca}^{2+}$ and has a slight impact on unit cell parameters. 
Table 1. Unit cell parameters and values of mean crystallite size.

\begin{tabular}{|c|c|c|c|c|c|}
\hline \multirow{2}{*}{ Sample } & \multicolumn{3}{|c|}{ Cell parameters, $\boldsymbol{A}$} & \multirow{2}{*}{$\begin{array}{c}\text { Cell volume, } \\
\mathbf{A}^{\mathbf{3}}\end{array}$} & $\begin{array}{c}\text { Mean crystallite } \\
\text { size, } \mathbf{n m}\end{array}$ \\
\cline { 2 - 4 } & $\mathbf{a}$ & $\mathbf{b}$ & $\mathbf{c}$ & 529.28 & 35 \\
\hline $\mathrm{HAp}$ & 9.424 & 9.424 & 6.882 & 528 & 23 \\
\hline 5Co10Ce:HAp & 9.421 & 9.421 & 6.867 & 527.81 & 35 \\
\hline 5Co10Ce/HAp & 9.423 & 9.423 & 6.881 & 529.15 & \\
\hline
\end{tabular}

The mean crystallite sizes were calculated from XRD patterns by using the Scherrer equation (Table 1). It should be noticed that the substitution with cobalt ions strongly affects the mean crystallite sizes of calcium hydroxyapatite. The introduction of cobalt cations into the HAp structure induces a reduction of crystallite size from $35 \mathrm{~nm}$ to $23 \mathrm{~nm}$. For 5 Co10Ce/HAp sample, the mean crystallite size is the same as for the support.

\section{Electron microscopy analysis}

TEM and SEM images of the samples are shown in Fig. 2. Electron microscopy analysis reveals a rod - like structure and nanoscale size of hydroxyapatite particles. The average length and width of pure hydroxyapatite particles are $87 \mathrm{~nm}$ and $28 \mathrm{~nm}$, respectively (Fig. 2a).

The presence of cobalt and cerium ions leads to slight changes in the shape of HAp particles but their size is visible lower for substituted sample. Moreover, the small and spherical particles are additionally observed (Fig. 2b,c). Based on the HRTEM and SEAD images (not shown), these particles are ascribed to the cerium phosphate (Fig. 2b) or dioxide (Fig. 2c) and cobalt oxide with spinel structure. Particle sizes of cerium phases and cobalt oxide are about $10 \mathrm{~nm}$ and $20 \mathrm{~nm}$, respectively.

Analysis of SEM images (Fig. 2d,e,f) showed that the catalysts exhibit slightly different textures depending on the preparation method. The $5 \mathrm{Co} 10 \mathrm{Ce} / \mathrm{HAp}$ sample is characterized by elongated grains and presented a similar morphology with pure HAp sample, whereas the 5Co10Ce:HAp material exhibits an irregular shape of particles. Various morphologies of the studied catalysts may be associated with position of cobalt and cerium ions. In substituted samples, $\mathrm{Ca}^{2+}$ ions were partially replaced by $\mathrm{Co}^{2+}$ and $\mathrm{Ce}^{3+}$ ions. Substitution of calcium ions by smaller cobalt ions changes the lattice parameters thus the shape of grains. In the catalyst prepared by incipient wetness impregnation method the active species are located on the support surface and no apparent changes of the initial morphology of support is detected. 

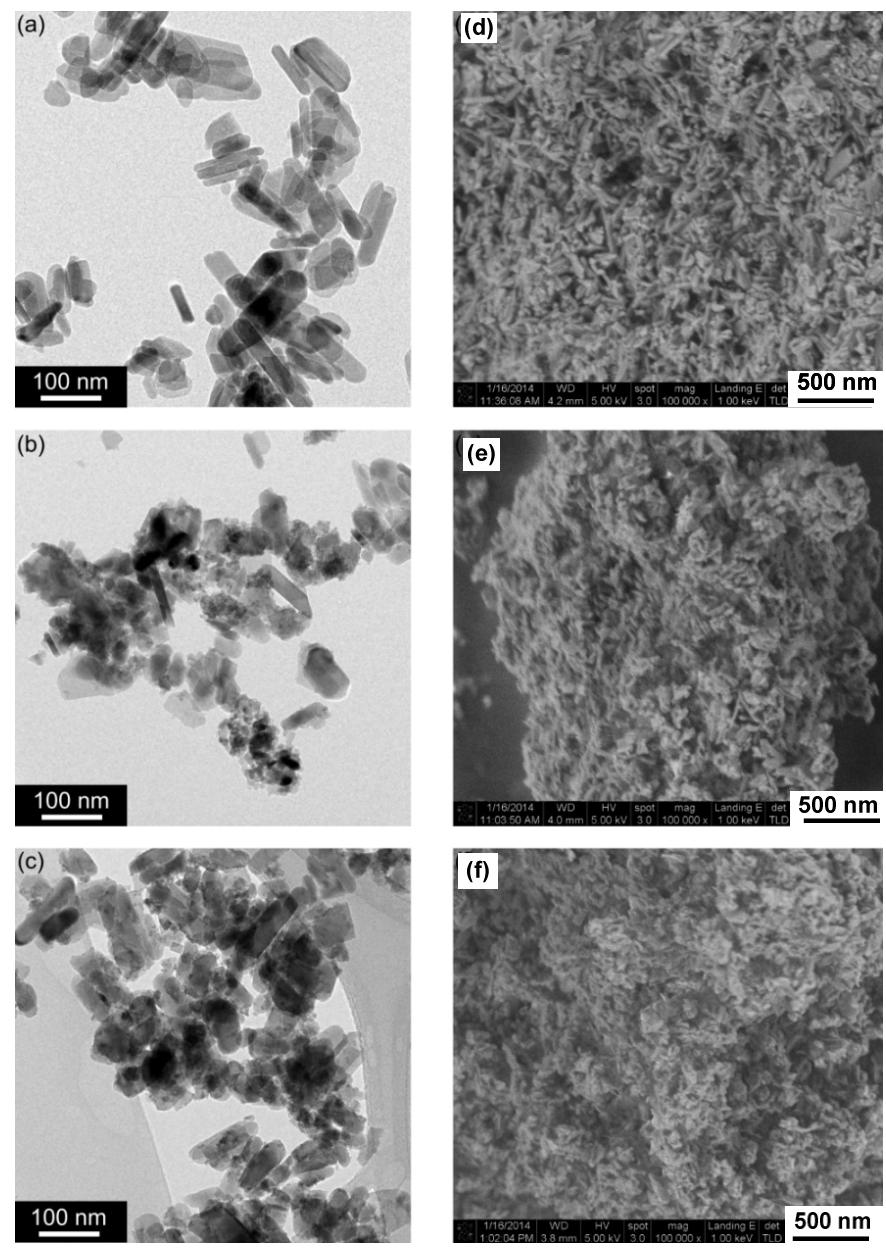

Fig. 2. Electron microscopy images of (a, d) HAp, (b, e) 5Co10Ce:HAp and (c, f) 5Co10Ce/HAp.

Chemical composition of prepared samples was analysed by the EDS measurements. As shown in Table 2, the cobalt and cerium contents are in good agreement with expected ones for 5Co10Ce:HAp catalyst. For $5 \mathrm{Co} 10 \mathrm{Ce} / \mathrm{HAp}$ sample, results of EDS analysis showed that cobalt and cerium contents were slightly lower than targeted ones.

To determine the pore structure and the specific surface area of the HAp samples, the $\mathrm{N}_{2}$ adsorption - desorption isotherms method was used. According to IUPAC classification, $\mathrm{N}_{2}$ adsorption - desorption isotherms correspond to a combination of Type II and Type IV isotherms with $\mathrm{H} 3$ hysteresis loop in the relative pressure $\left(p / p_{0}\right)$ range of $0.8-1.0$, as shown in 
Fig. 3. The obvious hysteresis loop is typical for materials with interparticle mesoporosity [41]. The presence of mesopores was substantiated by BJH differential pore volume plot (inset to Fig. 3) indicating that most of pores are in the range 5-40 nm. It can also be noticed that HAp and 5Co10Ce/HAp sample exhibit narrow pore-size distribution with maximum at $24 \mathrm{~nm}$ whereas 5Co10Ce:HAp sample shows a little broader distribution of pore diameter with maximum at $20 \mathrm{~nm}$.

Table 2. Results of EDS, physical sorption and TPD-NH 3 measurements.

\begin{tabular}{|c|c|c|c|c|c|}
\hline \multirow{2}{*}{ Sample } & \multicolumn{2}{|c|}{$\begin{array}{c}\text { Chemical } \\
\text { composition, wt } \%\end{array}$} & \multirow{2}{*}{$\begin{array}{l}\text { Total acidity, } \\
\mathrm{mmol} / \mathrm{g} \cdot 10^{-2}\end{array}$} & \multirow{2}{*}{$\begin{array}{l}\text { Specific surface } \\
\text { area, } \mathrm{m}^{2} / \mathrm{g}\end{array}$} & \multirow{2}{*}{$\begin{array}{l}\text { Pore volume, } \\
\mathrm{m}^{3} / \mathrm{g}\end{array}$} \\
\hline & Co & $\mathrm{Ce}$ & & & \\
\hline HAp & - & - & 5.51 & 53.13 & 0.34 \\
\hline 5Co10Ce:HAp & 5.09 & 10.04 & 20.71 & 88.62 & 0.37 \\
\hline 5Co10Ce/HAp & 4.64 & 9.65 & 11.99 & 42.19 & 0.20 \\
\hline
\end{tabular}

\section{Physical sorption}

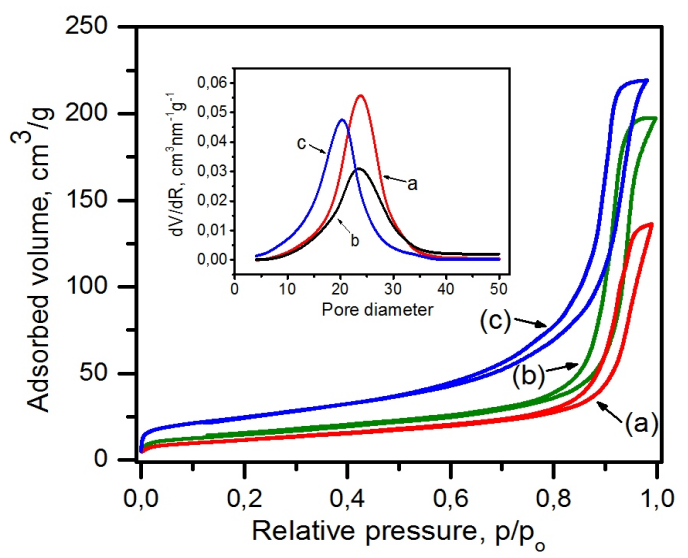

Fig. 3. $\mathrm{N}_{2}$ adsorption - desorption isotherms of (a) HAp, (b) 5Co10Ce/Hap,

(c) 5Co10Ce:HAp and corresponding pore size distributions as inlet.

The specific surface area and pore volume of studied catalysts are summarized in Table 2. It can be noticed that the catalyst prepared by the microwave-assisted hydrothermal method, in which the calcium ions were substituted with cobalt and cerium ions exhibits a higher specific surface area than the pure HAp. As was shown on TEM image (Fig. 2b), substituted 
HAp is characterized by smaller particle size in comparison to HAp, which can cause an increase in the surface area. On the other hand, the presence of $\mathrm{CePO}_{4}$ nanoparticles on the HAp surface (Fig. 2b) can also increase the specific surface area. Additionally, the $5 \mathrm{Co} 10 \mathrm{Ce}: \mathrm{HAp}$ exhibits a higher surface area then $5 \mathrm{Co} 10 \mathrm{Ce} / \mathrm{HAp}$ catalyst. According to XRD pattern (Fig. 1b), on the surface of the impregnated catalyst $\mathrm{Co}_{3} \mathrm{O}_{4}$ and $\mathrm{CeO}_{2}$ phases are present. These phases could increase the surface area. However, the $5 \mathrm{Co} 10 \mathrm{Ce} / \mathrm{HAp}$ catalyst exhibits the lower pore volume than pure HAp. It indicates that the $\mathrm{Co}_{3} \mathrm{O}_{4}$ and $\mathrm{CeO}_{2}$ particles are placed into the pore of the support and as a result decrease the surface area.

\section{FT - IR spectra}

FT - IR spectra of the studied HAp samples, shown in Fig. 4, confirm the formation of hydroxyapatite structure in all samples and contain characteristic absorption bands of HAp originating from hydroxyl and phosphate groups. The vibrational modes of $\mathrm{PO}_{4}{ }^{3-}$ tetrahedral apatite's structure are clearly observed at around at $480 \mathrm{~cm}^{-1}\left(\mathrm{v}_{2}\right), 565,601 \mathrm{~cm}^{-1}\left(\mathrm{v}_{4}\right), 962 \mathrm{~cm}^{-1}\left(\mathrm{v}_{1}\right)$ and 1033, $1090 \mathrm{~cm}^{-1}$ $\left(v_{3}\right)$ while sharp bands, detected at around $633 \mathrm{~cm}^{-1}\left(\mathrm{v}_{1}\right)$ and $3572 \mathrm{~cm}^{-1}\left(\mathrm{v}_{1}\right)$ correspond to bending and stretching mode of the hydroxyl groups in the channels of the structure [28]. Besides typical bands of HAp, a broad band in

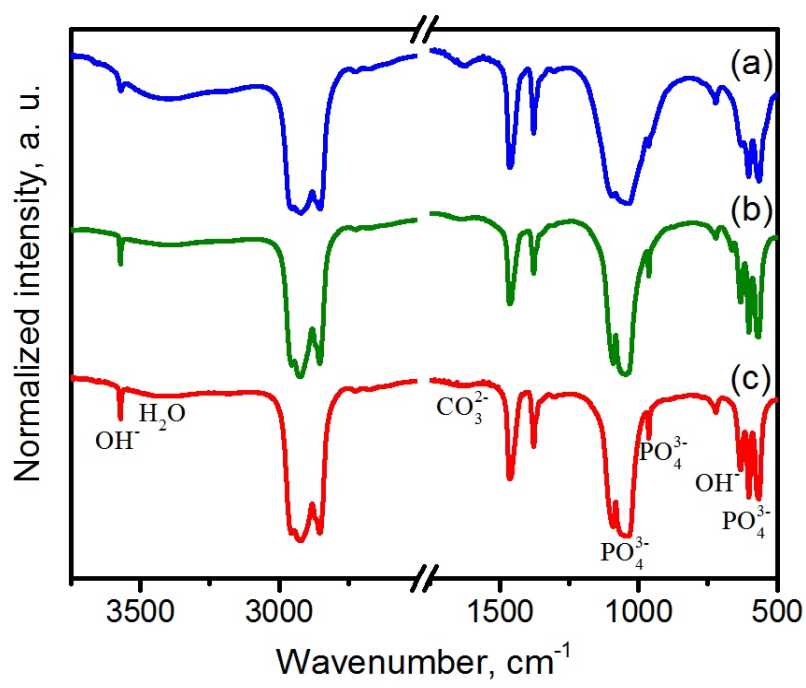

Fig. 4. FT-IR spectra of (a) 5Co10Ce:HAp, (b) 5Co10Ce/HAp and (c) HAp. 
the region around $3100-3550 \mathrm{~cm}^{-1}\left(\mathrm{v}_{1}\right)$ and weak band at around $1641 \mathrm{~cm}^{-1}$ are observed. The first band is associated with the $\mathrm{H}$ - bonding between the adsorbed water and hydroxyl ions in the hydroxyapatite structure [42], whereas the second is attributed to the vibration group of $\mathrm{CO}_{3}{ }^{2-}$. The presence of this band suggests the insignificant amount of carbonate substitution due to adsorption of $\mathrm{CO}_{2}$ from atmosphere [24-25]. For all materials, the FT - IR spectra also contain bands at 719,1385 and $1464 \mathrm{~cm}^{-1}$ assigned to nujol that was used during measurements.

The incorporation of Co ions into HAp structure leads to the decrease in the intensity of the structural $\mathrm{OH}^{-}$peaks at $633 \mathrm{~cm}^{-1}$ and $3572 \mathrm{~cm}^{-1}$. The decrease of intensity might be caused by the dehydroxylation attributable to cobalt substitution in the HAp lattice [43-44]. It is worth noting that the replacement of $\mathrm{Ca}^{2+}$ ions by $\mathrm{Co}^{2+}$ ions affects the width of the band originating from $\mathrm{PO}_{4}{ }^{3-}$ groups $\left(v_{1}\right)$. The band broadening can be ascribed to a decrease of sample crystallinity [45].

The FT-IR spectra of HAp and 5Co10Ce/HAp show that cobalt impregnation do not cause any significant change in bands shape and intensity. Nevertheless, $5 \mathrm{Co} 10 \mathrm{Ce} / \mathrm{HAp}$ spectrum contains one additional band at $667 \mathrm{~cm}^{-1}$, which corresponds to the stretching vibration of the metal-oxygen bond and confirms the formation of $\mathrm{Co}_{3} \mathrm{O}_{4}$ [46]. It is in agreement with result obtained from XRD analysis and TEM images.

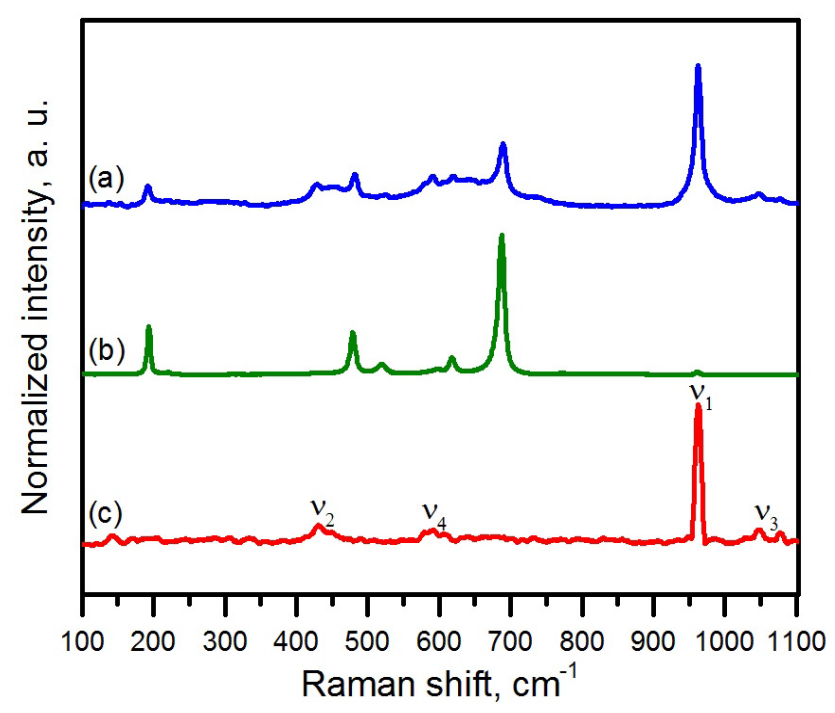

Fig. 5. Raman spectra of (a) 5Co10Ce:HAp, (b) 5Co10Ce/HAp and (c) HAp. 


\section{Raman spectra}

Figure 5 shows Raman spectra of hydroxyapatite promoted with cobalt and cerium ions. Results obtained for "pure" hydroxyapatite show typical bands of phosphate group [30,35, 45]. The strongest band at $963 \mathrm{~cm}^{-1}$ is assigned to the symmetric modes $\left(\mathrm{v}_{1}\right)$ of $\mathrm{PO}_{4}$ group. Other bands observed at around $433,600,1047$ and $1080 \mathrm{~cm}^{-1}$ correspond to bending vibration $\left(\mathrm{v}_{2}, \mathrm{v}_{4}\right)$ and asymmetric stretching vibration $\left(v_{3}\right)$ of phosphate ions. The modes of $\mathrm{PO}_{4}$ are observed for the promoted samples, too. However, the spectrum of $5 \mathrm{Co} 10 \mathrm{Ce} / \mathrm{HAp}$ displays very weak bands of $\mathrm{PO}_{4}$ group due to the presence of additional strong peaks (at 194, 482, 622 and $691 \mathrm{~cm}^{-1}$ ) of $\mathrm{Co}_{3} \mathrm{O}_{4}[30,46]$. It should be noted that the vibrational modes of $\mathrm{Co}_{3} \mathrm{O}_{4}$ are also seen in the spectrum of $5 \mathrm{Co} 10 \mathrm{Ce}: \mathrm{HAp}$. It suggests that part of cobalt ions did not substitute the calcium ions into $\mathrm{HAp}$ structure forming $\mathrm{Co}_{3} \mathrm{O}_{4}$ on hydroxyapatite surface. Moreover, for 5 Co10Ce:HAp sample, the peak broadening at $963 \mathrm{~cm}^{-1}$ (compared to HAp) can be noticed. The peak broadness is related to the replacement of $\mathrm{Ca}^{2+}$ ions by $\mathrm{Co}^{2+}$ ions in the HAp lattice [35].

\section{Acid - base properties}

To characterize the acid surface properties of the catalysts, the temperature-programmed desorption of $\mathrm{NH}_{3}$ was used. As can be seen from Table 2, pure HAp exhibits the lowest total acidity among studied samples. After calcium hydroxyapatite promotion with cobalt and cerium ions, the surface acidity increases in the following order: 5Co10Ce:HAp > 5Co $10 \mathrm{Ce} / \mathrm{HAp}>$ HAp.

\section{TPR $-\mathrm{H}_{2}$}

Results of TPR - $\mathrm{H}_{2}$ measurements are presented in Table 3 and Fig. 6. For 5Co 10Ce:HAp (Fig. 6a), two reduction regions are observed, the first one at low temperature range (below $500{ }^{\circ} \mathrm{C}$ ) and the second one at high temperature range (above $500{ }^{\circ} \mathrm{C}$ ). The $\mathrm{H}_{2}$ consumption below $500^{\circ} \mathrm{C}$ can be ascribed to the reduction of Co species, which are located on the HAp surface. The reduction taking place above $500^{\circ} \mathrm{C}$ corresponds to the reduction of cobalt ions, which substituted the calcium ions in HAp structure. In case of

Table 3. $\mathrm{H}_{2}$ consumption of $\mathrm{Co}$ and Ce promoted HAp catalysts.

\begin{tabular}{|l|c|c|c|c|c|c|c|c|}
\hline \multirow{2}{*}{ Sample } & \multicolumn{3}{|c|}{ Peak temperature, ${ }^{\circ} \mathrm{C}$} & \multicolumn{3}{c|}{$\mathrm{H}_{2}$ consumption, mol/g 10 } \\
\cline { 2 - 9 } & (I) & (II) & (III) & (IV) & (I) & (II) & (III) & (IV) \\
\hline $5 \mathrm{Co} 10 \mathrm{Ce}: \mathrm{HAp}$ & \multicolumn{2}{|c|}{355} & 657 & 783 & \multicolumn{2}{|c}{0.364} & 0.691 & 0.035 \\
\hline $5 \mathrm{Co} 10 \mathrm{Ce} / \mathrm{HAp}$ & 314 & 373 & - & - & 0.382 & 1.013 & - & - \\
\hline
\end{tabular}


5Co10Ce/HAp (Fig. 6b) sample, the TPR profile contains two distinct reduction peaks at temperature below $500^{\circ} \mathrm{C}$. These peaks are ascribed to $\mathrm{Co}_{3} \mathrm{O}_{4}$ reduction. Cobalt oxide $\left(\mathrm{Co}_{3} \mathrm{O}_{4}\right)$ is reduced in the following two steps $[3,9$, 30]:

$$
\begin{aligned}
\mathrm{Co}_{3} \mathrm{O}_{4}+\mathrm{H}_{2} & \rightarrow 3 \mathrm{CoO}+\mathrm{H}_{2} \mathrm{O} \\
\mathrm{CoO}+\mathrm{H}_{2} & \rightarrow \mathrm{Co}+\mathrm{H}_{2} \mathrm{O}
\end{aligned}
$$

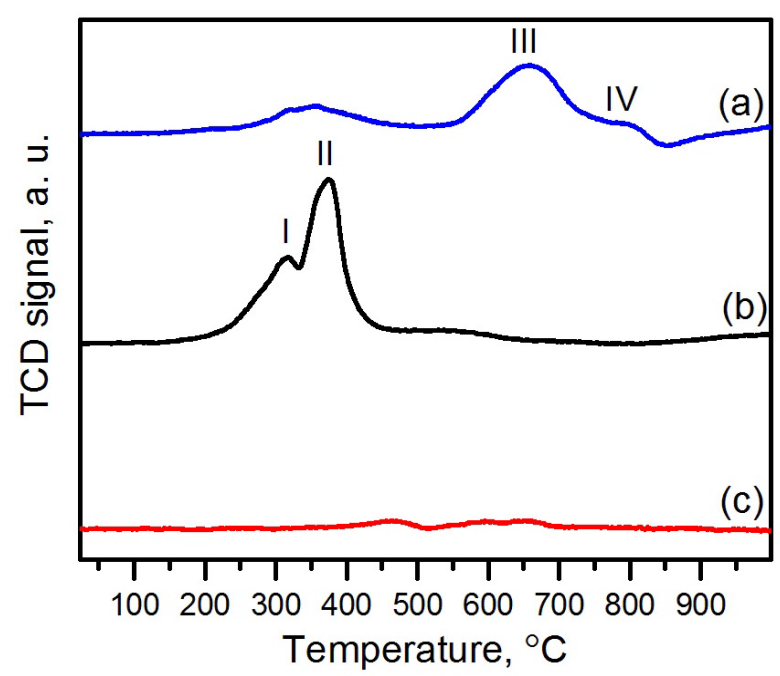

Fig. 6. TPR $-\mathrm{H}_{2}$ profiles of (a) 5Co10Ce:HAp, (b) 5Co10Ce/HAp and (c) HAp.

According to the above reaction equations, the $\mathrm{H}_{2}$ consumption ratio of second peak to the first one should be as $3: 1$. Table 3 shows that this ratio is lower than 3. It suggests, that some of cobalt ions could be incorporated into the hydroxyapatite structure in $5 \mathrm{Co} 10 \mathrm{Ce} / \mathrm{HAp}$ sample. Although, one cannot exclude the possibility of ceria reduction in this region. TPR $-\mathrm{H}_{2}$ results show also that pure HAp (Fig. 6c) was not reduced in the temperature range studied, which is in line with literature data [29-32].

\section{XPS measurements}

XPS measurements were performed in order to determine the surface oxidation state of cobalt and cerium in the samples. XPS spectrum in the Co $2 p$ region of the 5 Co10Ce:HAp catalyst (Fig. 7a) show peak at 
$782,1 \mathrm{eV}$ that is assigned to the Co $2 \mathrm{p}_{3 / 2}$ of $\mathrm{Co}^{+}$located at the $\mathrm{Ca}^{2+}$ position in the hydroxyapatite structure, along with apparent satellite peak at $786,8 \mathrm{eV}$. The satellite peak can be ascribed to the shake-up excitation of the high-spin $\mathrm{Co}^{2+}$ ions [47]. As was suggested by K. Elkabouss et al. [28] the intense satellite peak as well as the binding energy of Co $2 p_{3 / 2}$ peak corresponds well with $\mathrm{Co}^{2+}$ oxidation state. For $5 \mathrm{Co} 10 \mathrm{Ce} / \mathrm{HAp}$, the Co $2 \mathrm{p}_{3 / 2}$ peak is observed at 780,1 eV (Fig. 7b) what is slightly lower than for the 5Co10Ce:HAp sample but it is in agreement with literature data for $\mathrm{Co}_{3} \mathrm{O}_{4}$ spinel $[28,48]$.

Ce3d regions of catalysts are presented in Fig. 7c, d. XPS spectrum of 5Co10Ce:HAp catalyst (Fig. 7c) contains the two peaks at around 883,7 $\mathrm{eV}$ and $901,4 \mathrm{eV}$. These peaks correspond to the spin - orbit split Ce $3 \mathrm{~d}_{5 / 2}$ and $\mathrm{Ce} 3 \mathrm{~d}_{3 / 2}$, respectively [49-50]. Both peaks have the satellite structure. Their satellites are observed at $885,6 \mathrm{eV}$ and 904,5 , respectively. The spectrum is characteristic to $\mathrm{Ce}^{3+}$ oxidation state and match well to XPS spectra reported in the literature for $\mathrm{CePO}_{4}$ [49-50].

The Ce3d region of $5 \mathrm{Co} 10 \mathrm{Ce} / \mathrm{HAp}$ (Fig. 7d) is different from that observed for the 5Co10Ce:HAp. Six peaks corresponding to three pairs of spin - orbit doublets can be identified. The peaks at around $882 \mathrm{eV}$ and $900,5 \mathrm{eV}$ are the $3 d_{5 / 2}$ and $3 d_{3 / 2}$, respectively [48]. The spin - orbit splitting between these peaks is about $18 \mathrm{eV}$. The peaks at $887,9 \mathrm{eV}$ and 898,2 eV are the satellites associated to the $3 d_{5 / 2}$, whereas the highest binding energy peaks (at $906,5 \mathrm{eV}$ and $916,3 \mathrm{eV}$ ) are the satellite peaks connected with the $3 d_{3 / 2}$ [38]. The peak located at $916,3 \mathrm{eV}$ is typical to $\mathrm{Ce}^{4+}[49-50]$.

The XPS spectra confirmed the results of XRD measurements and TEM images about the cobalt and cerium compounds formed on hydroxyapatite surface. As was shown before, on the $\mathrm{HAp}$ surface, $\mathrm{Co}_{3} \mathrm{O}_{4}$ and $\mathrm{CeO}_{2}$ are observed for $5 \mathrm{Co} 10 \mathrm{Ce} / \mathrm{HAp}$ and $\mathrm{CePO}_{4}$ for 5Co10Ce:HAp. Therefore, the formed compounds are strongly depended on the promotion method.

Additionally, the XPS spectra can give some information about acid base properties. According to K.E. Elkabouss et al. [28] the binding energy of $01 \mathrm{~s}$ is sensitive to the change of sample basicity. The authors noticed that the binding energy of O1s change from about $529 \mathrm{eV}$ (for the most basic oxide) to $533 \mathrm{eV}$ (for the most acid oxide). Binging energy of O1s (not shown) for $5 \mathrm{Co} 10 \mathrm{Ce}: \mathrm{HAp}$ is higher than for $5 \mathrm{Co} 10 \mathrm{Ce} / \mathrm{HAp}$ indicates that the sample prepared by the incipient wetness method is more basic than the sample obtained by microwave - assisted method. This result is in good agreement with the TPD - $\mathrm{NH}_{3}$ measurements. 


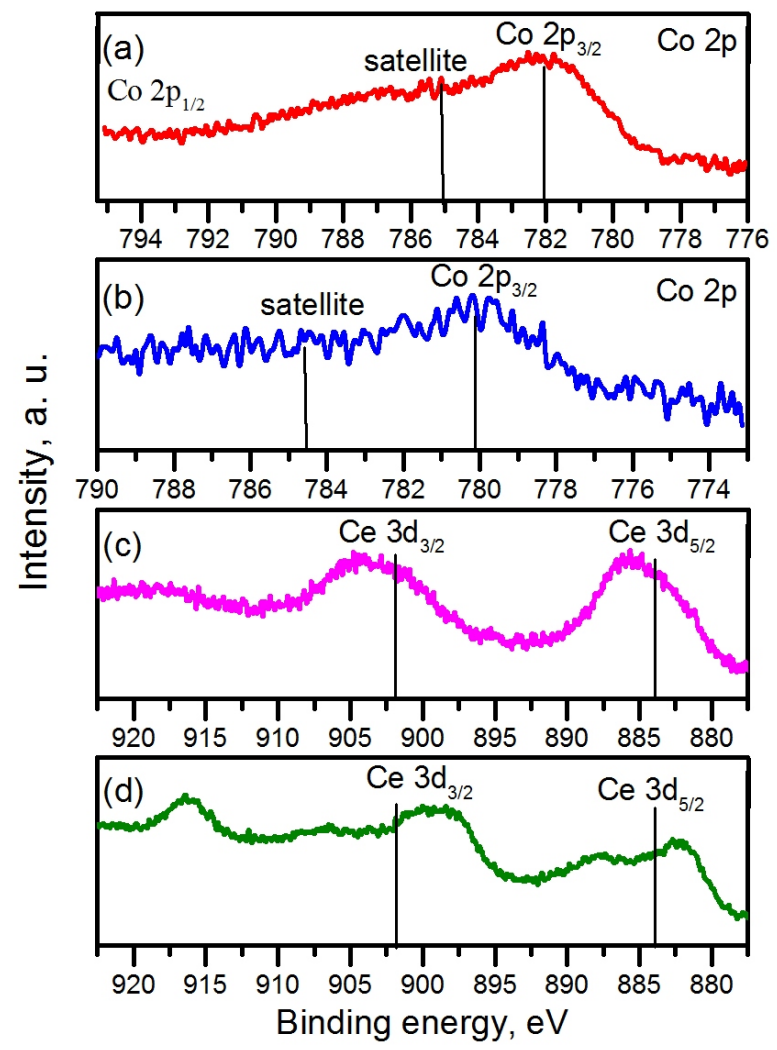

Fig. 7. XPS spectra of the Co $2 p$ region for (a) 5Co10Ce:HAp, (b) 5Co10Ce/HAp and $\mathrm{Ce} 3 \mathrm{~d}$ regions for (c) 5Co10Ce:HAp, (d) for 5Co10Ce/HAp.

\section{Catalysts performance}

Catalytic activity of the samples was evaluated in SRE to determine ethanol conversion, hydrogen yield and distribution of reaction products during 6 hours at $450^{\circ} \mathrm{C}$ with a constant ethanol/water ratio (1:6). First, catalytic performance of HAp was examined and results are shown in Fig. 8. The pure HAp exhibits the low catalytic activity for SRE in terms of ethanol conversion and hydrogen yield as well as products distribution. The pure HAp shows only $8 \%$ of ethanol conversion and $6 \%$ of hydrogen produced in the last hour of process. Moreover, the main products formed over HAp catalyst were acetaldehyde and carbon monoxide (Fig. 8b). High amount of these compounds in reaction products suggests that the major reaction takes place over this sample is dehydrogenation (reaction 5). 


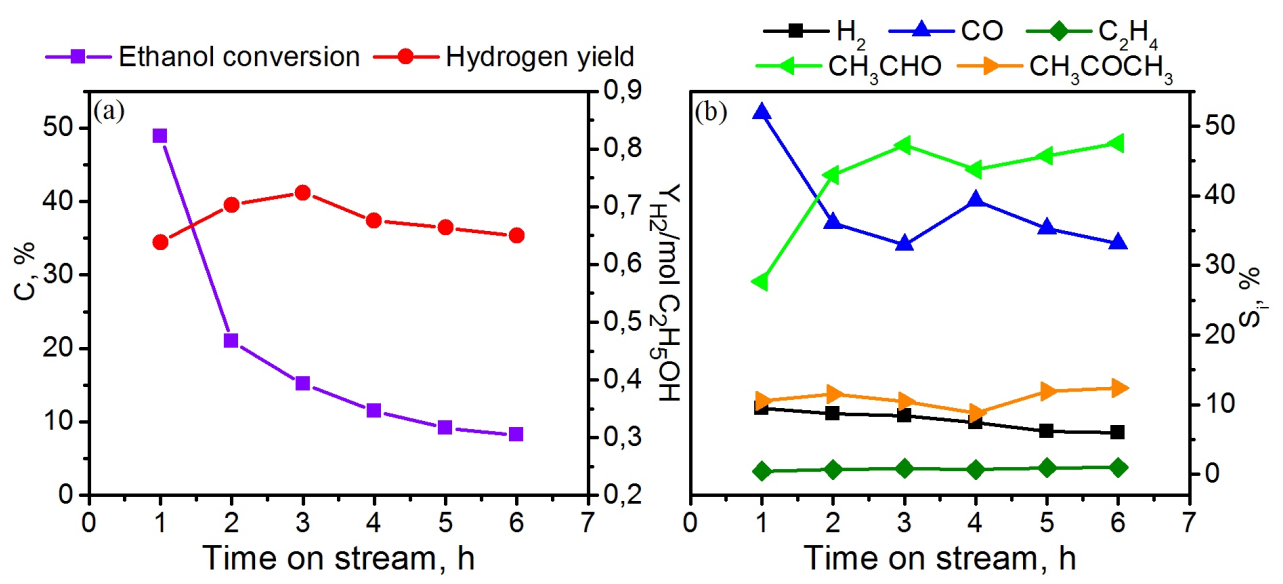

Fig. 8. (a) Ethanol conversion, hydrogen yield and (b) products distribution as a function of reaction time over HAp.

Ethanol dehydrogenation occurs on the base centres of the catalysts, which correspond with TPD - $\mathrm{NH}_{3}$ measurements (Table 2). Results obtained for HAp showed that the surface acidity of HAp is the lowest among the studied samples. Fig. $8 \mathrm{~b}$ also shows that carbon dioxide is not formed over HAp. It points out that the steam reforming reaction (reaction 1) does not occur at all.

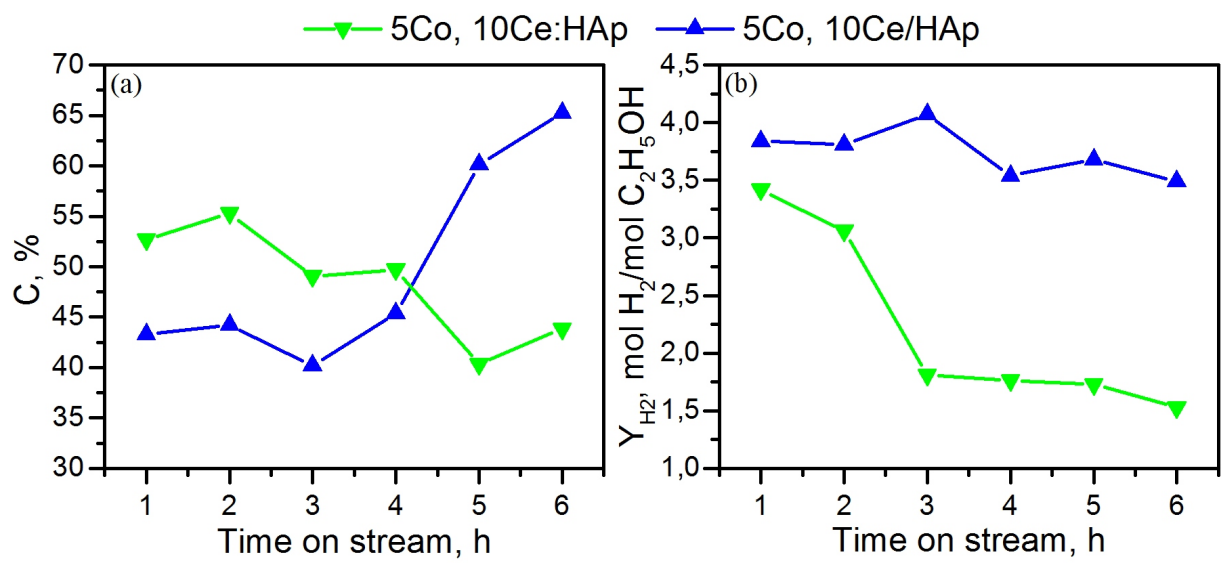

Fig. 9. (a) Ethanol conversion and (b) hydrogen yield as a function of reaction time over HAp promoted with cobalt and cerium ions. 
The catalytic performance of hydroxyapatite promoted with cobalt and cerium ions in the ethanol steam reforming process was determined under the same conditions as for the pure HAp. Fig. 9 presents the ethanol conversion and hydrogen yield results as a function of reaction time for 5Co10Ce:HAp and 5Co10Ce/HAp catalysts. Analysis of the obtained data indicates that the promotion of calcium hydroxyapatite with cerium and cobalt ions improves both the conversion of ethanol and hydrogen yield. Studied catalysts demonstrate a comparably high conversion in the range of $40 \%$ to $65 \%$. However, the ethanol conversion decreases with time on stream for 5Co10Ce:HAp, whereas for 5Co10Ce/HAp increases after 3 hours of the test. It can be explained by different acidity of the studied catalysts. TPD $\mathrm{NH}_{3}$ measurements (Table 2) show that the 5Co10Ce:HAp have more acid centres on surface in comparison to $5 \mathrm{Co} 10 \mathrm{Ce} / \mathrm{HAp}$ catalyst. Additionally, these catalysts are characterized by different reduction properties, which can also have the impact on catalytic activity. As was shown from TPR profiles, the catalyst prepared by incipient wetness impregnation method is reduced at lower temperature than the $5 \mathrm{Co} 10 \mathrm{Ce}: \mathrm{HAp} . \mathrm{Co}_{3} \mathrm{O}_{4}$ on the surface of $5 \mathrm{Co} 10 \mathrm{Ce} / \mathrm{HAp}$ catalyst is reduced to $\mathrm{CoO}$ and metallic Co under reaction conditions. It means that amounts of $\mathrm{CoO}$ and metallic $\mathrm{Co}$ increase during the test what can improve the conversion of ethanol as well as ensure a high hydrogen yield (more than $3,5 \mathrm{~mol} \mathrm{H}_{2} / \mathrm{mol} \mathrm{C}_{2} \mathrm{H}_{5} \mathrm{OH}$ ). It should be noticed that reduction is a necessary step to achieve a high catalytic activity as was already suggested by Byram et. al. [3]. Moreover, the results of Tuti and Pepe studies [51] indicate that activation of cobalt catalysts under reaction conditions, milder with respect to the reduction pre-treatment in $\mathrm{H}_{2}$, would be responsible of lesser metallic active phase sintering. As a consequence, higher hydrogen yield over no activated in pure $\mathrm{H}_{2}$ catalysts can be obtained. In the 5Co10Ce:HAp sample, the cobalt ions are located in calcium hydroxyapatite structure. Therefore, in comparison with $5 \mathrm{Co} 10 \mathrm{Ce} / \mathrm{HAp}$, the 5Co10Ce:HAp sample contains hard to reduce cobalt species and only little is reduced to metallic Co. As a result, the ethanol conversion can decrease with time on stream. The reduction properties of 5Co10Ce:HAp can also effect on $\mathrm{H}_{2}$ yield that decrease during the ethanol steam reforming, too.

Products distributions as a function of reaction time are presented in Fig. 10. Reaction products contain seven compounds: $\mathrm{H}_{2}$ (hydrogen), $\mathrm{CO}_{2}$ (carbon dioxide), $\mathrm{CO}$ (carbon monoxide), $\mathrm{CH}_{4}$ (methane), $\mathrm{C}_{2} \mathrm{H}_{4}$ (ethylene), $\mathrm{CH}_{3} \mathrm{CHO}$ (acetaldehyde) and $\mathrm{CH}_{3} \mathrm{COCH}_{3}$ (acetone). The presence of these products indicates that both acid and basic sites are active in the ethanol steam reforming process. However, a slight amount of ethylene (produced on acid sites) allows to assume that the basic sites are more active in this process. 

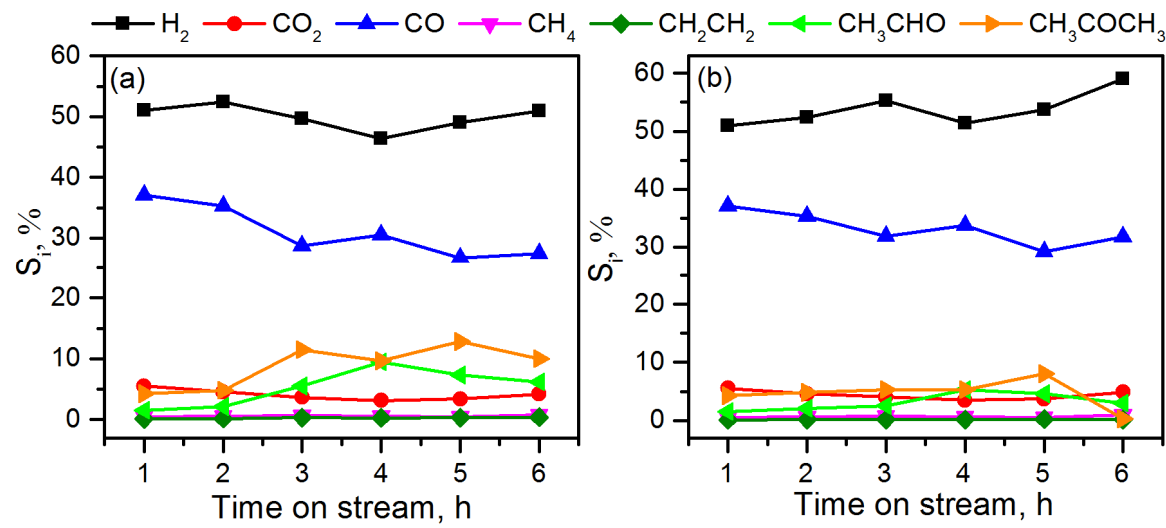

Fig. 10. Products distribution as a function of reaction time over (a) 5Co10Ce:HAp and (b) 5Co10Ce/HAp.

It should be noticed that hydrogen is the main component of the reaction product for both promoted with cobalt and cerium ions HAp catalysts (Fig. 9). At the same time, these catalysts form higher amount of carbon monoxide than carbon dioxide. It suggests that the reaction pathway favoured by these catalysts is incomplete ethanol steam reforming to hydrogen and carbon monoxide (reaction 3). As can be seen from Fig. 10, the share of $\mathrm{CO}$ in reaction products decreases with time on stream what would suggest the proceeding of water gas - shift reaction (WGS, reaction 4) or catalytic methanation. However, there is on increase in $\mathrm{CO}_{2}$ or $\mathrm{CH}_{4}$ at the same time. Generally, the WGS reaction is a significant stage for ethanol steam reforming process due to the conversion of $\mathrm{CO}$ to $\mathrm{CO}_{2}$ and $\mathrm{H}_{2}$ through reaction with steam. Carbon monoxide has an adverse effect upon catalytic activity because it can poison the catalysts (reaction 8) and that's why the reforming of ethanol is carried out in the presence of steam, which reduce the formation of carbon monoxide [12].

Compared with 5Co10Ce/HAp, for 5Co10Ce:HAp the increase of acetone and acetaldehyde was observed. It can be a result of dehydrogenation process (reaction 2) or ethanol decomposition to acetone, carbon monoxide and hydrogen. On the other hands, the acetone can be formed over 5Co10Ce:HAp catalyst from acetaldehyde by using the cerium oxide. According to Nishiguchi et. al. [6] the acetone is obtained from acetaldehyde via three sequential steps: dehydrogenation of ethanol to acetaldehyde, aldol condensation and aldol reaction with lattice oxygen on $\mathrm{CeO}_{2}$.

Fig. 10 reveals that the catalyst prepared by incipient wetness impregnation method ensures a better distribution of products than the catalyst obtained by substitution of calcium ions by cobalt and cerium ions. 
The $5 \mathrm{Co} 10 \mathrm{Ce} / \mathrm{HAp}$ ensures a higher amount of hydrogen that slightly increases during the test. Moreover, this catalyst exhibits a lower share of acetone and acetaldehyde in reaction products. Similar results' concerning the preparation method was reported by Wang et al. [52]. They studied the cobalt catalysts supported on ceria, prepared by coprecipitation and impregnation methods, and found that the presence of easily reducible $\mathrm{Co}_{3} \mathrm{O}_{4}$ on the ceria surface leads to a higher catalytic activity. Over $10 \% \mathrm{Co}_{3} \mathrm{O}_{4} / \mathrm{CeO}_{2}$ catalyst, ethanol conversion was close to $100 \%$ and $\mathrm{H}_{2}$ selectivity was about $70 \%$ at $450{ }^{\circ} \mathrm{C}$. Effect of the preparation method on cobalt catalysts applied to SRE process was also studied by Garcia and Assaf [53]. The authors pointed out that both the support synthesis method (solvothermal or precipitation) and the way of cobalt incorporation (impregnation or deposition-precipitation) were essential for obtaining efficient catalyst for the hydrogen production. Although ethanol conversion was superior of $99 \%$ at $600{ }^{\circ} \mathrm{C}$ for all catalysts, catalysts prepared by deposition-precipitation method presented the greater hydrogen yield. It was suggested that better catalytic performance of Co catalysts, due to the appropriate synthesis technique, could be attributed to the improved metal phase dispersion, enhanced metal-support interaction and increased metal-support interface [54]. Additionally, in this paper the influence of the incorporation method of active phase on the acid-base properties of the catalysts was emphasized. It is known that catalyst acidity is one of the main factors determining the catalytic properties for hydrogen production via SRE process.

\section{CONCLUSIONS}

Calcium hydroxyapatites promoted with cobalt and cerium ions show promising catalytic activity for hydrogen production via ethanol steam reforming. Promotion with cobalt and cerium ions significantly improves the ethanol conversion, hydrogen yield and products distribution for HAp catalysts. It was found that the catalytic performance depends on the preparation method in terms of the acid-base and reduction properties. The catalyst obtained by the incipient wetness impregnation method exhibits a higher hydrogen yield (more than $3,5 \mathrm{~mol} \mathrm{H}_{2} / \mathrm{mol} \mathrm{C}_{2} \mathrm{H}_{5} \mathrm{OH}$ ) and increasing ethanol conversion with time on stream, which can be a result of easier reduction of cobalt species and lower surface acidity. Over these catalysts, mainly the ethanol steam reforming to hydrogen and carbon monoxide was observed. Further research over calcium hydroxyapatite promoted with higher cobalt loadings and other active ions will be conducted. 


\section{EXPERIMENTAL SECTION}

\section{Catalysts preparation}

\section{Direct Microwave-assisted hydrothermal synthesis}

As precursors, $\left(\mathrm{NH}_{4}\right)_{2} \mathrm{HPO}_{4}(\mathrm{POCH}), \mathrm{Ca}\left(\mathrm{NO}_{3}\right)_{2} \cdot 4 \mathrm{H}_{2} \mathrm{O} \quad(\mathrm{POCH})$, $\mathrm{Co}\left(\mathrm{NO}_{3}\right)_{2} \cdot 6 \mathrm{H}_{2} \mathrm{O}(\mathrm{POCH})$ and $\mathrm{Ce}\left(\mathrm{NO}_{3}\right)_{3} \cdot 6 \mathrm{H}_{2} \mathrm{O}$ (ACROS) were used. All reagents were separately dissolved in distilled water. Afterwards, $\left.\left(\mathrm{NH}_{4}\right)_{2} \mathrm{HPO}_{4}\right)$ solution was added to the solution containing an appropriate amount of $\mathrm{Ca}\left(\mathrm{NO}_{3}\right)_{2} \cdot 4 \mathrm{H}_{2} \mathrm{O}, \mathrm{Ce}\left(\mathrm{NO}_{3}\right)_{3} \cdot 6 \mathrm{H}_{2} \mathrm{O}$ and $\mathrm{Co}\left(\mathrm{NO}_{3}\right)_{2} \cdot 6 \mathrm{H}_{2} \mathrm{O}$ under vigorous stirring. The suspension was precipitated by adding drop-by-drop $25 \%$ solution of ammonia $(\mathrm{POCH})$ until the $\mathrm{pH}$ attained 10,5 . Then, the as-prepared precipitate was transferred into Teflon vessel and placed into a microwave autoclave for $1 \mathrm{~h}$ at $200^{\circ} \mathrm{C}$. After hydrothermal treatment, the product was filtered and washed with distilled water and ethanol $(\mathrm{POCH})$ several times. Finally, the obtained powder was dried at $80^{\circ} \mathrm{C}$ overnight and calcined at $500^{\circ} \mathrm{C}$ for $3 \mathrm{~h}$ under atmospheric conditions. Calcium hydroxyapatite substituted with cobalt and cerium ions obtained in this way was denoted as 5Co10Ce:HAp (5 and 10 correspond to the expected mass percentage in the sample). Pure calcium hydroxyapatite (without Co and Ce ions) was also obtained by the abovementioned method.

\section{Incipient wetness impregnation method}

Pure HAp sample (prepared by the microwave-assisted hydrothermal method) was impregnated using aqueous solution of $\mathrm{Co}\left(\mathrm{NO}_{3}\right)_{2} \cdot 6 \mathrm{H}_{2} \mathrm{O}$ and $\mathrm{Ce}\left(\mathrm{NO}_{3}\right)_{3} \cdot 6 \mathrm{H}_{2} \mathrm{O}$. After cobalt and cerium ions incorporation, the sample was dried at $30^{\circ} \mathrm{C}$ for $24 \mathrm{~h}$ and calcined in air at $500^{\circ} \mathrm{C}$ for $3 \mathrm{~h}$. As a result, catalyst with $5 \mathrm{wt} \%$ Co and $10 \mathrm{wt} \%$ Ce was obtained. Impregnated sample was denoted as $5 \mathrm{Co} 10 \mathrm{Ce} / \mathrm{HAp}$.

\section{Catalysts characterization}

The structure of catalysts was analyzed by X-Ray powder diffraction method (XRD) using an X'PertPro HighScore Plus (PANalytical Ltd.) diffractometer with a Ni-filtered CuKa radiation $(1,54060 \AA)$ from $10^{\circ}$ to $80^{\circ}$. The crystalline phase was identified by comparison with PDF standard. Unit cell parameters were refined by the least-squares method with the aid of X'Pert HighScore Plus program. The Scherrer formula was used to calculate the mean crystallite size of studied catalysts. 
Electron microscopy was used to characterize the morphology of the prepared samples. The TEM images were performed using Philips CM20 Super-Twin transmission electron microscope operating at $200 \mathrm{kV}$ with $0,25 \mathrm{~nm}$ resolution. The SEM images were acquired by FESEM FEI Nova NanoSEM 230 scanning electron microscopy. EDS (Energy Dispersive X-Ray Spectroscopy) was employed to determine the surface chemical composition of the prepared samples. EDS measurements were performed using SEM equipped with EDAX spectrometer.

The surface area and pore volume were measured by the $\mathrm{N}_{2}$ adsorption/ desorption isotherms at liquid nitrogen temperature, using Sorptometic 1990. Before the measurement the catalyst was degassed at $200^{\circ} \mathrm{C}$ for $2 \mathrm{~h}$ under vacuum. The Brunauer-Emmett-Teller (BET) method was used to calculate the specific surface area while Barret-Joyner-Halenda (BJH) for pore size and volume analysis.

Fourier Transform Infrared spectra (FT - IR) were collected with a Bruker IFS-88 spectrometer equipped with a FRA-106 (laser Nd:YAG, $1064 \mathrm{~nm}$ ) over the range of wavenumber $4000-50 \mathrm{~cm}^{-1}$.

Raman spectra were measured with a Renishaw InVia Raman spectrometer equipped with a diode laser $(830 \mathrm{~nm})$, confocal DM 2500 Leica optical microscope and thermoelectrically Ren Cam CDD detector.

Hydrogen temperature-programmed reduction $\left(\mathrm{TPR}-\mathrm{H}_{2}\right)$ measurements were carried out in an AutoChem II 2920 analyzer equipped with a thermal conductivity detector (TCD). Sample was placed in $U$-shaped quartz reactor and heated from room temperature to $1000^{\circ} \mathrm{C}$ (heating rate $5^{\circ} \mathrm{C} / \mathrm{min}$ ). A mixture 5 vol\% hydrogen in argon $(50 \mathrm{ml} / \mathrm{min})$ was used as a gas carrier at the flow rate of $50 \mathrm{ml} / \mathrm{min}$. Hydrogen consumption was evaluated using the CuO standard.

X-ray Photoelectron spectra (XPS) were collected on a XPS, UHV spectrometer SPECS equipped with a dual Al/Mg X-ray source and PHOIBOS 100 analyzer. Data analysis was performed using SPECLAB Software. Line of background was calculated by Shirley methods. The carbon C 1s 284,8 $\mathrm{eV}$ line was used as reference.

Surface acidity was determined by temperature-programmed desorption of ammonia (TPD - $\mathrm{NH}_{3}$ ). Sample (mesh 0,2-0,4 mm) was placed in the reactor and heated (heating rate $10^{\circ} \mathrm{C} / \mathrm{min}$ ) in argon stream $(30 \mathrm{ml} / \mathrm{min}$ ) up to $550^{\circ} \mathrm{C}$, for the removal of adsorbed contaminants. Next, the sample was cooled down to $180^{\circ} \mathrm{C}$ and then the adsorption of ammonia was conducted. Then, physically adsorbed ammonia was removed by stream of argon. Finally, the catalyst was heated from $180^{\circ} \mathrm{C}$ to $550^{\circ} \mathrm{C}$ in stream of argon and amount of ammonia desorbed was determined by TCD detector. 


\section{Activity test}

Catalytic performance tests for SRE process were carried out in a fixed bed quartz tubular reactor ( $8 \mathrm{~mm}$ diameter) over the catalyst sample (particle size between $0,45-0,75$ Tyler mesh) heated in a nitrogen stream $(22 \mathrm{ml} / \mathrm{min})$ at $450^{\circ} \mathrm{C}$. The temperature was measured by using thermocouple placed over the catalytic bed. The aqueous ethanol solution with water to ethanol molar ratio 6:1 was delivered into the reactor through a pump (Perkin Elmer). The mixture of $\mathrm{EtOH}+\mathrm{H}_{2} \mathrm{O}$ was vaporized in heater before introduction on the catalyst bed. The gas hourly space velocity (GHSV) was maintained at $26000 \mathrm{~h}^{-1}$. The analysis of the reagents and reaction products was made by using a gas chromatograph (with a flame ionization detector (FID) and TCD detector) equipped with two packed columns filling Poropak $Q$ and type $S$ of active carbon.

The catalytic performance was characterized by ethanol conversion (denoted as $C$ ), hydrogen yield (denoted as $Y_{H_{2}}$ ) and products distribution (denoted as $S_{i}$ ). They were calculated according to the Eqs. (12)-(14):

$\mathrm{C}=\left(\mathrm{N}_{\mathrm{C} 2 \mathrm{H} 5 \mathrm{OH}(\mathrm{IN})}-\mathrm{N}_{\mathrm{C} 2 \mathrm{H} 5 \mathrm{OH}(\mathrm{OUT})}\right) / \mathrm{N}_{\mathrm{C} 2 \mathrm{H} 5 \mathrm{OH}(\mathrm{IN})} 100 \%$

$\mathrm{Y}_{\mathrm{H} 2}=\mathrm{N}_{\mathrm{H} 2} /\left(6 \cdot \mathrm{N}_{\mathrm{C} 2 \mathrm{H} 5 \mathrm{OH}(\mathrm{IN})}\right) 100 \%$

$S_{1}=X_{1} / \Sigma_{1} X_{1} 100 \%$

where $\mathrm{N}_{\mathrm{C} 2 \mathrm{H} 5 \mathrm{OH}(\text { in) }}$ - moles of inlet ethanol, $\mathrm{N}_{\mathrm{C} 2 \mathrm{H} 5 \mathrm{OH} \text { (out) }}$ - moles of outlet ethanol, $\mathrm{N}_{\mathrm{H} 2}$ - moles of hydrogen produced, $\mathrm{X}_{\mathrm{i}}-$ mole of $\mathrm{i}$ product in gaseous products of SRE.

\section{ACKNOWLEDGEMENTS}

The authors are thankful MSc E. Bukowska for XRD data, MSc L. Krajczyk for TEM studies, Prof. J. Baran for FT - IR measurements and Dr. M. Ptak for Raman data.

\section{REFERENCES}

1. A. Kumar, R. Prasad, Y.C. Sharma, International Journal of Environmental Research, 2014, 4, 203.

2. C.D. Dave, K.K. Pant, Renewable Energy, 2011, 36, 3195.

3. B. Bayram, I.I. Soykal, D. von Deak, J.T. Miller, U.S. Ozkan, Journal of Catalysis, 2011, 284, 77. 
4. H. Muroyama, R. Nakase, T. Matsui, K. Eguchi, International Journal of Hydrogen Energy, 2010, 35, 1575.

5. C.C.R.S. Rossi, C.G. Alonso, O.A.C. Antunes, R. Guirardello, L. Cardozo-Filho, International Journal of Hydrogen Energy, 2009, 34, 323.

6. T. Nishiguchi, T. Matsumoto, H. Kanai, K. Utani, Y. Matsumura, W.-J. Shen, S. Imamura, Applied Catalysis A-General, 2005, 279, 273.

7. D.K. Liguras, D.I. Kondarides, X.E. Verykios, Applied Catalysis B- Environmental, 2003, 43, 345.

8. A.G.M. da Silva, P.A. Robles-Dutenhefner, A. Dias, H.V. Fajardo, A.S.P. Lovón, J.J. Lovón-Quintana, G.P. Valenca, Journal of Sol-Gel Science and Technology, 2013, 67, 273.

9. A.F. Lucredio, J.D.A. Bellido, A. Zawadzki, E.M. Assaf, Fuel, 2011, 90, 1424.

10. P.V. Snytnikov, S.D. Badmaev, G.G. Volkova, D.I. Potemkin, V.D. Belyaev, M.M. Zaryanova, Hydrogen Energy, 2012, 37(21), 16388.

11. A. N. Fatsikostas, X. E. Verykios, Journal of Catalysis, 2004, 225, 439.

12. R.C. Cerritos, R.F. Ramírez, A.F.A. Alvarado, J.M.M. Rosales, T.V. García, G. Esquivel, Industrial \& Engineering Chemistry Research, 2011, 50, 2576.

13. T. Hou, S. Zhang, T. Xu, W. Cai, Chemical Engineering Journal, 2014, 255, 149.

14. J.L. Contreras, J. Salmones, J.A. Colin-Luna, L. Nuno, B. Quintana, I. Cordova, B. Zeifert, C. Tapia, G.A. Fuentes, International Journal of Hydrogen Energy, 2014, 39, 18835.

15. H. Song, L. Zhang, R.B. Watson, D. Braden, U.S. Ozkan, Catalysis Today, 2007, 129, 346.

16. M.S. Batista, R.K.S. Santos, E.M. Assaf, E.A. Ticianelli, Journal of Power Sources, 2003, 124, 99.

17. J. Llorca, N. Homes, J. Sales, P. Ramirez de la Piscina, Journal of Catalysis, 2002, 209, 306.

18. J.L. Contreras, J. Salomones, L.A. Garcia, A. Ponce, B. Zeifert, G.A. Fuentes, Journal of New Materials for Electrochemical Systems, 2008, 11(2), 109.

19. S.S.Y. Lin, D.H. Kim, S.Y. Ha, Catalysis Letters, 2008, 122(3-4), 295.

20. B. Banach, A. MacHocki, P. Rybak, A. Denis, W. Grzegorczyk, W. Gac, Catalysis Today, 2011, 176(1), 28.

21. H. Wang, J.L. Ye, Y. Liu, Y.D. Li, Y.N. Qin, Catalysis Today, 2007, 129, 305.

22. F. Ma, W. Chu, L. Huang, X. Yu, Y. Wu, Chinese Journal of Catalysis, 2011, 32, 970.

23. A. Kaddouri, C. Mazzocchia, Catalysis Communications, 2004, 5, 339.

24. K. Agrawal, G. Singh, D. Puri, S. Prakash, Journal of Minerals and Materials Characterization and Engineering, 2011, 10, 727.

25. P.K. Tank, K.S. Chudasama, V.S. Thaker, M.J. Joshi, Journal of Nano-particle Research, 2013, 15, 1644.

26. R.-B. Suen, S.-C. Lin, W.-H. Hsu, Journal of Chromatography A, 2004, 1048, 31.

27. S. Ogo, A. Onda, K. Yanagisawa, Applied Catalysis A-General, 2008, 348, 129.

28. K. Elkabouss, M. Kacimi, M. Ziyad, S. Ammar, F. Bozon-Verduraz, Journal of Catalysis, 2004, 226, 16.

29. J. Ashok, N. Kumar, M. Subrahmanyam, A. Venugopal, Catalysis Letters, 2007, 121, 283. 
30. B. Aellach, A. Ezzamarty, J. Leglise, C. Lamonier, J. F. Lamonier, Catalysis Letters, 2010, 135, 197.

31. S. Sugiyama, T. Shono, D. Makino, T. Moriga, H. Hayashi, Journal of Catalysis, 2003, 214, 8.

32. L. Hakim, Z. Yaakob, M. Ismail, W.R.W. Daud, R. Sari, Chemical Papers, 2013, 67, 703.

33. M. Rakap, S. Özkar, Catalysis Today, 2012, 183, 17.

34. Y. Han, S. Li, X. Wang, X. Chen, Materials Research Bulletin, 2004, 39, 25.

35. Z. Stojanović, L. Veselinović, S. Marković, N. Ignjatović, D. Uskoković, Materials and Manufacturing Processes, 2009, 24, 1096.

36. G.C. Koumoulidis, A.P. Katsoulidis, A.K. Ladavos, P.J. Pomonis, C.C. Trapalis, A.T. Sdoukos, T.C. Vaimakis, Journal of Colloid and Interface Science, 2003, 259, 254.

37. D. Gopi, S. Nithiya, L. Kavitha, J. M. F. Ferreira, Bulletin of Materials Science, 2012, 35, 1195.

38. W. Suchanek, Materiały Ceramiczne, 2005, 2, 58.

39. J. Dobosz, S. Hull, M. Zawadzki, Polish Journal of Chemical Technology, 2016, 18, 59.

40. Yasukawa, K. Gotoh, H. Tanaka, K. Kondori, Colloid Surface A: Physicochemical and Engineering Aspects, 2012, 393, 53.

41. P.A. Webb, C. Orr, "Analytical methods in fine particle technology", Micromeritics Instrument Corporation, Norcross, Georgia, 1997, chapter 3.

42. R.R. Sheha, Journal of Colloid and Interface Science, 2007, 310, 18.

43. S.M. Sallam, K.M. Tohami, A.M. Sallam, L.I. Abo Salem, F.A. Mohamed, J. Biophysical Chemistry, 2012, 3, 278.

44. N. Devi Ravi, R. Balu, T.S. Sampath Kumar, Journal of the American Ceramic Society, 2012, 95, 2700.

45. V. Aina, G. Lusvardi, B. Annaz, I.R. Gibson, F.E. Imrie, G. Malavasi, L. Menabue, G. Cerrato, G. Martra, Journal of Materials Science: Materials in Medicine, 2013, 529-530, 88.

46. S. Farhadi, K. Pourzare, S. Sadeghinejad, Journal of Nanostructure in Chemistry, 2013, 3, 1.

47. E. Kramer, E. Itzkowitz, M. Wei, Ceramics International, 2014, 40, 13480.

48. L. Xue, C. Zhang, H. He, Y. Teraoka, Applied Catalysis B-Environmental, 2007, $75,167$.

49. R. Asuvathraman, K.I. Gnanasekar, P.C. Clinsha, T.R. Ravindran, K.V. Govindan Kutty, Ceramics International, 2015, 41, 3731.

50. E. Bêche, P. Charvin, D. Perarnau, S. Abanades, G. Flamant, Surface and Interface Analysis, 2008, 40, 264.

51. S. Tuti, F. Pepe, Catalysis Letters, 2008, 122, 196.

52. H. Wang, J.L. Ye, Y. Liu, Y.D. Li, Y.N. Qin, Catalysis Today, 2007, 129, 305.

53. S.R. Garcia, J.M. Assaf, Modern Research in Catalysis, 2012, 1, 52.

54. S. Song, B. Tan, U.S. Ozkan, Catalysis Letters, 2009, 132, 422. 